\title{
Is judicial inefficacy increasing the weight of the house property market in Spain? Evidence at the local level
}

\author{
Juan S. Mora-Sanguinetti
}

Received: 2 September 2010 / Accepted: 25 April 2011 / Published online: 31 May 2011

(C) The Author(s) 2011. This article is published with open access at SpringerLink.com

\begin{abstract}
The weight of the housing tenancy market in Spain is very low. It is frequently argued that an ineffective judicial system, implying a cumbersome procedure to evict a non-paying tenant or simply requiring a long period to execute a decision, may be an important determinant of the tenancy market's weakness, as it constrains the effective supply by reducing the profitability of landlords. This research studies this effect econometrically using a panel data approach and exploring differences in judicial efficacy among the Spanish provinces. After controlling for several other factors, this study concludes that the degree of inefficacy of the judicial system has a positive impact on the property share among provinces in Spain.
\end{abstract}

Keywords Judicial efficacy · Property market · Tenancy market . Contract enforcement

JEL Classification $\mathrm{K} 40 \cdot \mathrm{R} 21$

\footnotetext{
I am grateful to participants in the seminar of the Banco de España-Eurosystem and to Stefano Battilossi, Ángel Estrada, Pablo Hernández de Cos, Llanos Matea, Carmen Martínez Carrascal, Paloma López García, Jorge Martínez Pagés, Claire McHugh and to the three anonymous referees who reviewed this paper and its working paper version for their useful comments and suggestions. I am also in debt with María Gil for her assistance and preparation of the graphs. The views expressed are those of the author and should not be attributed to the Banco de España, the Eurosystem or the OECD.
}

J. S. Mora-Sanguinetti $(\bowtie)$

Economic Analysis and Forecasting Department, Banco de España-Eurosystem, Alcalá 48, 28014 Madrid, Spain

e-mail: juansmora@hotmail.com

J. S. Mora-Sanguinetti

OECD, Paris, France 


\section{Introduction}

Since the Spanish Civil War (1936-1939) the weight of the housing property market has persistently increased in Spain (in contrast to developments in the rental market). Although the official statistical information available is very scarce, the census database reveals that the proportion rose from 63.4 to $82.2 \%$ between 1970 and 2001 . Moreover, according to the estimations of the Spanish Ministry of Housing (2008), the average property rate rose by a further 2.1 percentage points in the period 2001-2007.

Several factors may have affected the evolution of the property share in Spain over the last decades. These factors include the fall in interest rates (Blanco and Restoy 2007), especially after 1995; liberalization of the banking sector since 1980 (Kumbhakar and Lozano-Vivas 2004; Iacoviello and Minetti 2003), more stringent tenancy laws having been adopted following World War II (Mora-Sanguinetti 2011), and a fiscal regime which favors buying over renting (López García 1996; GarcíaVaquero and Martínez 2005).

Several studies have pointed out that the factors mentioned above are not exclusive to Spain and that the increase in the property rate can be found in several other markets of the European Union as well as in the United States (Louvot-Runavot 2001). Nevertheless, the relative weakness of the tenancy market as compared to the property market in Spain is somewhat exceptional. This situation is generally regarded as undesirable for several economic reasons. The most important one is perhaps that a weak tenancy market is linked to lower mobility of individuals and workers (Maclennan et al. 1998; Barceló 2006) which tends to increase the unemployment rate (Layard et al. 1991) and to reduce the economy's efficiency (Hardman and Ioannides 1999). More recently, Arce and López-Salido (2007) have emphasized that a well-developed housing rental sector can be a crucial device to avoid housing price bubbles and the excessive concentration of resources in the building sector.

Despite these problems, and the imbalances entailed thereby, especially during the recent housing boom in Spain, the Spanish authorities have only paid attention to them recently. One such example is personal income tax deduction (IRPF) for the purchase of a primary residence. This measure has been maintained by all national Governments (irrespective of political orientation) for public choice reasons, despite its effect being to favor buying over renting (as mentioned above), its undesirable redistributive effects (Sanz 2000; Bilbao Terol et al. 2006) or its effects in prices (López García 2004). Only very recently it has been proposed its abrogation (under the 2011 Budget Law). ${ }^{1}$

Some time earlier, in 2009, the Government passed a Law $^{2}$ introducing new regulatory measures with the objective to protect the owners of rented dwellings. These reforms were intended to improve the functioning of the tenancy market, and thus, to reduce the weight of the property market. Those measures included, on the one hand, reform of the Spanish "Civil Procedural Law" $(\mathrm{CPL})^{3}$ in order to expedite evictions

\footnotetext{
${ }_{1}^{1}$ Law 39/2010 of 23 December 2010 (de presupuestos generales del Estado para el año 2011).

${ }^{2}$ Law 19/2009 of 23 November 2009 (de medidas de fomento y agilización procesal del alquiler y de la eficiencia energética de los edificios).

${ }^{3}$ Law 1/2000, of 7 January 2000 (de enjuiciamiento civil).
} 
and to facilitate the collection of rents by property owners (see further discussions in Sect. 2) and, on the other hand, reform of the Spanish Tenancy Law ${ }^{4}$ giving the owner more legal grounds to reduce the term of the tenancy contract. The latter reform was quite limited in scope and, as with all other substantive rules of the Spanish Tenancy Law, does not form part of this study as it is not subject to any regional variation.

Underlying those latter measures is the idea that both a slow judicial system (implying a cumbersome procedure to evict a non-paying tenant or simply a lengthy period to execute a decision) and unduly onerous rules governing tenancy contracts (such as rules limiting the landlord's ability to recover the flat for his own use) have been detrimental to the tenancy market as they have reduced the effective supply and may have contributed to lowering the share of rented dwellings.

A theoretical explanation of how judicial inefficacy may affect the flow of demand and supply of housing is provided later in this paper. In any case it is important to emphasize at the outset that the decision to rent a house on the market (or part thereof as is assumed below) involves transaction costs that do not exist (or at least are different) in the market for home ownership.

In other words, the renting of a home implies a sustained relationship in time with the figure of the tenant, which does not exist in the opposite case. That relationship is linked to the functioning of the judicial system in the sense that, in the presence of an ineffective judicial system (and therefore, under weakly controlled contractual arrangements), some tenants may default on their contractual obligations (such as paying the rent or taking care of the property). Those circumstances imply a reduction in the landlord's profits. The flow of benefits provided by rental housing thus depends on the correct application in time of the rental contracts. This need not occur in the case of complete ownership of a dwelling.

In addition to the judicial system, there are other control mechanisms in the market for home ownership (the discussion of which is beyond the scope of this paper) such as the property registry. An analysis of the role of property registration and other forms of property enforcement may be consulted in Arruñada (2003). In any case, as discussed below, it is possible to control by various inefficiencies that may exist in the mortgage lending market through alternative judicial system measures (discussed below).

In summary, in this context, a proportion of potential landlords may disappear from the market in the event of weak enforcement being provided by the judicial system. This would imply an increase in the rate of property in the economy. ${ }^{5}$

That is the general result found on an international basis by some papers in the economic literature, for instance Casas-Arce and Saiz (2010). Those authors used the measure of judicial formalism (as a proxy of inefficacy) of Djankov et al. (2003) to explain the decision between owning and renting in a set of countries and found that more formalism may be expected to reduce the weight of the tenancy market. Djankov et al. (2003) proposed a measure of formalism of the judicial system when evicting a non-paying tenant. They concluded that higher formalism is related to more difficult

\footnotetext{
4 Law 29/1994, of 24 November 1994 (de arrendamientos urbanos).

5 A discussion of how the judicial system works when dealing with tenancy conflicts is included below in Sect. 2 .
} 
evictions and higher unpredictability of the procedures. ${ }^{6}$ This paper specifically aims to analyze the impact of an ineffective judicial system in Spain on the housing tenure outcomes by exploiting the cross-province variation existing in the weight of the house property market in Spain and in the performance of the judicial system. Landlords are supposed to exit the tenancy market when they face an environment in which it is difficult to enforce their tenancy contracts. Thus, this paper aims to assess to what extent the efficacy functioning of the judicial system explains the varying weights of the property market in the Spanish provinces once other concurrent factors are taken into account.

In order to do that, I have constructed an index of judicial efficacy for each province of Spain based on official judicial data. ${ }^{7}$ Then, its impact in the property share is estimated after controlling for a set of other relevant economic and demographic factors.

The structure of this paper is as follows. Section 2 presents a descriptive analysis of the cross province variation of the property rate in Spain and constructs the judicial efficacy measure used in the main estimations. Section 3 explores the empirical literature on the topic and provides a theoretical justification for the hypothesis tested in this paper. Section 4 presents the estimations using panel data techniques. Finally, Sect. 5 presents the findings of this study. Appendix A presents alternative estimations when other judicial efficacy measures are taken into account.

\section{Measuring judicial efficacy and the property rate in the Spanish economy}

An owner who wants to collect an unpaid rent or evict a tenant for any reason (nonpayment of rent, vandalism of property) in Spain has to use the procedures established by the CPL (2000). ${ }^{8}$ The CPL (2000) is the basic procedural regulation of the judicial system. It establishes the rules of access to the court system, the formal procedures that the parties must observe, the role of the judge, the rules governing the admission and use of evidence, the control exercised by superior courts and all related issues. Therefore that Law is a main determinant of the "aggregated" slow (or fast) performance of the judicial system in Spain (Mora-Sanguinetti 2010). Although it is a national Law, its application differs among the Spanish provinces. A rational explanation for that is that the workload of the judges may differ among the provinces. This may be partially implied by the difference in populations falling with the jurisdiction of the court or the various levels of litigation (generated by either the population or the number of

\footnotetext{
6 The results and methodology by Djankov et al. (2003), although very relevant, cannot be used in the experiment proposed in this paper because, as mentioned, they concern international elements for a specific year. Therefore, they cannot capture the variations in efficiency within a specific country. The latter may be caused by differences in the application of the Civil Procedural Law and not by the Civil Procedural Law itself (see further Mora-Sanguinetti 2010).

7 Other indices are also constructed and tested in Appendix A of this paper.

8 It should be noted that some extrajudicial solutions may be found by the parties, such as sending the case to arbitration. However, only a judge can order an eviction in Spain.
} 
lawyers per capita). ${ }^{9}$ At the same time, the resources invested in the administration of justice differ from region to region. ${ }^{10}$ The key issue is thus to define a correct measure of judicial inefficacy. This section (and Appendix A of this paper) is directed to that task. It is in fact possible to observe that the efficacy of the judicial system diverges among the different regions of Spain over time (allowing the construction of a panel with information on the functioning of the judicial system). As argued before, we may expect that in the most ineffective regions, where it is more difficult to evict a nonpaying tenant or to have the payment of rent enforced through the judicial system, landlords will opt to quit the tenancy market, and thus the share of tenancy in the province will diminish (see Sect. 3.2 for a further theoretical discussion).

In order to construct a set of judicial system indicators useful for the analysis of the housing market, a relevant question arises: what are the specific procedures required to recover an unpaid rent in Spain? The CPL (2000) establishes a specific procedure for recovering such debt: first, a "declaratory judgment" will "declare" the existence of the debt and the obligation of the debtor to pay. We can call that element the "first stage" or "first procedure" because the possibility remains that the tenant decides not to pay the debt. In that case, a final or definitive procedure ("executory process") takes place. In the "execution" stage, the creditor asks the judge to "execute" the debt. As a result of this final procedure, the judge will seize the amount from the bank accounts of the debtor and will probably order his eviction from the dwelling.

The General Council of the Judicial Power (Consejo General del Poder Judicial, CGPJ) neither collects nor publishes data on the duration of legal proceedings in the Spanish courts. However, information can be gleaned from its database reporting the number of cases filed, resolved and still pending in the Spanish judicial system by subject, region, court ${ }^{11}$ and year. Using that database, a relative measure of efficacy can be constructed for the enforcement of each procedure: the congestion rate (see Eq. 1 below). The congestion rate is defined as the ratio between the sum of pending cases (measured at the beginning of the period) plus new cases in a specific year and the cases resolved in that same year (Padilla et al. 2007). A lower congestion rate is related to greater efficacy of the judicial system.

$$
\text { Congestion rate }_{i, t}=\frac{{\text { Pending } \text { cases }_{i, t}+\text { New }_{\text {cases }}, t}_{i, t}}{\text { Cases resolved }_{i, t}}
$$

Three more relative measures of inefficacy are computed in Appendix A: the "resolution rate", the "pending cases rate" and the "pending-plus-new cases rate" ( $p p n c$ in the tables). As discussed below in Sect. 4.1, alternative estimates including a measure of

\footnotetext{
${ }^{9}$ It should be noted, however, that both the effect of population and litigation in this relationship are taken into account in the different specifications of the model developed in this paper.

10 The "Comunidades Autónomas" (regions) have some powers related to the administration of justice in Spain. Even though the "judicial power" is not properly transferred to the regions, management of resources of the judicial system is influenced by the policies developed by the regions. For instance, they decide how much money is invested in new courts each year in their territories, even though the new courts are integrated in a centrally governed system.

11 The courts analyzed in this study are the "juzgados de primera instancia" and the "juzgados de primera instancia e instrucción". Those are the courts available for the parties at first instance.
} 
Table 1 Judicial system variables

\begin{tabular}{llllllr}
\hline Type of procedure & Variable & Obs & Mean & Std. Dev. & Min & Max \\
\hline Declaratory & Prtcongestion & 350 & 1.53 & 0.36 & 1.03 & 4.17 \\
Declaratory & Prtresolution & 350 & 0.92 & 0.14 & 0.39 & 1.18 \\
Declaratory & Prtpendency & 350 & 0.41 & 0.16 & 0.13 & 1.59 \\
Execution & Excongestion & 350 & 3.97 & 1.20 & 1.20 & 9.99 \\
Execution & Exresolution & 350 & 0.87 & 0.20 & 0.42 & 2.02 \\
Execution & Expendency & 350 & 2.77 & 0.98 & 0.46 & 7.59 \\
Execution & ppnc*1000 & 350 & 17.39 & 7.78 & 0.78 & 36.96 \\
Mortgage & Mortcongestion & 350 & 2.72 & 0.98 & 0.36 & 8.50 \\
Mortgage & Mortresolution & 350 & 1.03 & 0.41 & 0.22 & 3.67 \\
Mortgage & Mortpendency & 350 & 1.62 & 0.62 & 0.09 & 5.29 \\
Mortgage & Mortppnc & 350 & 0.72 & 0.45 & 0.01 & 2.81 \\
\hline Soure: CGPJ & selfelaboration & & & & &
\end{tabular}

Source: CGPJ (2010) and self elaboration

"litigation" by province (calculated as the number of lawyers per capita) (following Carmignani and Giacomelli 2010) have been provided. The introduction of these "per capita" measures allow for a robustness exercise as the population differs quite significantly between different provinces.

The CGPJ offers homogeneous data for the various procedures for the period 20012007. ${ }^{12}$ For the purposes of the analysis herein, I have chosen the provincial level, although more disaggregated data on the judicial system is available (at the level of a particular court and judicial district (partido judicial)). This is due to the lack of more disaggregated data in other variables such as income per capita (or the PPP corrections). Another disadvantage of this should be noted. The rental market is mainly a local market, so when agents take their decisions, their probable point of reference is the situation in a sub-provincial market (their specific city and not the situation in other cities within the same province). However, an analysis at the provincial level remains valuable as we can assume that agents in a province are more likely to be aware of, and influenced by, problems in the judicial system in the surrounding markets than those of the rest of the country.

In the tables the prefix " $p r t$ " precedes the efficacy measure related to procedures in the "declaratory stage" (or as we called it, "first" procedure): prtcongestion. The prefix "ex" precedes the efficacy measure related to the executions: excongestion. Table 1 shows the descriptive statistics for those computations (also for the alternative efficacy measures studied in Appendix A). Table 2 shows the results for the congestion rate when studied for the executions (excongestion) in the period 2001-2007. ${ }^{13}$

An average congestion rate of 3.97 over the period 2001-2007 (see Table 1) indicates that around four cases (summing up the pending cases and the new cases arriving

\footnotetext{
$\overline{12}$ Note that the new CPL (2000) entered into force on 7 January 2001. This new CPL radically changed several aspects of civil procedure in Spain (Mora-Sanguinetti 2010) and therefore it is not advisable to relate the data after 2001 with previous observations.

13 Excluding Ceuta and Melilla (no information is available for these regions).
} 
Table 2 Judicial congestion rate by province (execution)

\begin{tabular}{|c|c|c|c|c|c|c|c|}
\hline Province & 2001 & 2002 & 2003 & 2004 & 2005 & 2006 & 2007 \\
\hline Álava & 1.20 & 1.88 & 1.25 & 2.62 & 4.28 & 1.23 & 2.28 \\
\hline Albacete & 3.81 & 3.00 & 4.78 & 3.01 & 2.95 & 2.46 & 3.49 \\
\hline Alicante & 3.77 & 4.68 & 6.01 & 4.46 & 5.72 & 6.23 & 5.64 \\
\hline Almería & 3.08 & 4.38 & 3.92 & 4.14 & 3.54 & 3.60 & 4.11 \\
\hline Avila & 2.52 & 1.85 & 3.48 & 2.95 & 4.19 & 5.64 & 3.74 \\
\hline Badajoz & 3.30 & 3.76 & 3.25 & 3.28 & 3.81 & 3.95 & 4.52 \\
\hline Baleares & 3.44 & 3.30 & 4.94 & 6.70 & 6.36 & 8.99 & 9.47 \\
\hline Barcelona & 4.07 & 4.80 & 5.34 & 4.79 & 4.76 & 4.99 & 4.98 \\
\hline Burgos & 2.31 & 3.28 & 3.14 & 2.79 & 3.36 & 3.16 & 2.95 \\
\hline Cáceres & 3.92 & 5.93 & 3.41 & 4.62 & 3.31 & 3.28 & 4.32 \\
\hline Cádiz & 3.55 & 3.29 & 3.71 & 3.99 & 3.08 & 4.89 & 3.91 \\
\hline Castellón & 4.72 & 5.50 & 9.99 & 5.33 & 5.40 & 6.42 & 5.95 \\
\hline Ciudad Real & 3.62 & 5.50 & 6.89 & 4.11 & 5.02 & 5.02 & 5.30 \\
\hline Córdoba & 2.13 & 3.08 & 3.52 & 4.92 & 3.69 & 3.15 & 2.79 \\
\hline A Corurña & 3.56 & 3.96 & 3.24 & 3.70 & 4.27 & 4.39 & 4.60 \\
\hline Cuenca & 2.99 & 4.81 & 4.11 & 4.26 & 5.48 & 5.56 & 4.84 \\
\hline Girona & 2.87 & 4.33 & 3.77 & 4.24 & 4.23 & 4.70 & 5.30 \\
\hline Granada & 2.62 & 3.07 & 3.48 & 4.04 & 3.81 & 5.94 & 4.53 \\
\hline Guadalajara & 6.14 & 3.99 & 4.58 & 5.20 & 2.80 & 4.43 & 5.78 \\
\hline Guipúzcoa & 2.12 & 1.94 & 1.65 & 2.00 & 2.52 & 2.68 & 2.39 \\
\hline Huelva & 2.89 & 3.51 & 2.76 & 3.52 & 3.92 & 4.82 & 3.79 \\
\hline Huesca & 2.69 & 3.88 & 4.31 & 2.90 & 2.97 & 3.27 & 3.93 \\
\hline Jaén & 2.54 & 2.47 & 3.63 & 3.45 & 3.37 & 3.32 & 3.16 \\
\hline León & 3.46 & 3.98 & 4.88 & 3.49 & 4.36 & 3.18 & 5.54 \\
\hline Lleida & 4.52 & 4.31 & 5.01 & 4.13 & 4.47 & 4.50 & 5.30 \\
\hline La Rioja & 2.75 & 2.32 & 2.93 & 3.99 & 3.95 & 3.15 & 3.43 \\
\hline Lugo & 2.83 & 2.75 & 2.57 & 2.51 & 2.89 & 3.67 & 4.30 \\
\hline Madrid & 3.83 & 4.66 & 5.22 & 5.23 & 4.89 & 5.74 & 5.53 \\
\hline Málaga & 3.04 & 3.45 & 3.30 & 3.89 & 4.05 & 3.98 & 4.07 \\
\hline Murcia & 5.34 & 4.88 & 4.53 & 4.83 & 5.32 & 5.39 & 4.78 \\
\hline Navarra & 2.87 & 4.67 & 3.84 & 3.99 & 4.56 & 5.16 & 4.06 \\
\hline Ourense & 3.92 & 2.91 & 3.16 & 3.43 & 4.04 & 4.47 & 4.86 \\
\hline Asturias & 4.05 & 3.90 & 4.26 & 3.91 & 4.31 & 4.01 & 4.14 \\
\hline Palencia & 2.88 & 3.27 & 2.58 & 4.40 & 4.58 & 3.08 & 4.13 \\
\hline Las Palmas & 3.07 & 4.56 & 6.16 & 4.61 & 5.13 & 5.16 & 4.89 \\
\hline Pontevedra & 2.72 & 3.25 & 3.19 & 3.46 & 3.86 & 5.23 & 4.11 \\
\hline Salamanca & 2.16 & 3.42 & 2.55 & 2.90 & 2.32 & 3.35 & 3.04 \\
\hline Santa Cruz de Tenerife & 2.91 & 3.03 & 4.65 & 4.51 & 5.55 & 5.17 & 4.99 \\
\hline Cantabria & 2.85 & 2.89 & 3.44 & 3.45 & 4.05 & 3.84 & 3.15 \\
\hline Segovia & 2.51 & 2.68 & 3.20 & 3.08 & 2.54 & 3.85 & 3.96 \\
\hline
\end{tabular}


Table 2 continued

\begin{tabular}{llllllll}
\hline Province & 2001 & 2002 & 2003 & 2004 & 2005 & 2006 & 2007 \\
\hline Sevilla & 2.83 & 3.25 & 3.81 & 3.58 & 3.33 & 4.23 & 5.17 \\
Soria & 4.42 & 2.62 & 3.84 & 1.90 & 2.32 & 3.43 & 2.96 \\
Tarragona & 4.22 & 4.62 & 4.64 & 4.69 & 3.81 & 4.88 & 4.75 \\
Teruel & 3.25 & 6.07 & 5.56 & 5.41 & 5.17 & 6.11 & 4.75 \\
Toledo & 4.38 & 3.98 & 4.48 & 4.77 & 4.40 & 5.27 & 3.88 \\
Valencia & 5.23 & 5.71 & 6.12 & 5.29 & 5.64 & 6.39 & 6.13 \\
Valladolid & 1.30 & 4.28 & 2.10 & 4.03 & 3.86 & 4.07 & 3.72 \\
Vizcaya & 1.76 & 1.80 & 2.69 & 1.91 & 2.83 & 2.64 & 2.21 \\
Zamora & 3.62 & 3.58 & 3.22 & 2.77 & 2.76 & 3.75 & 3.93 \\
Zaragoza & 2.98 & 4.70 & 4.84 & 3.52 & 4.18 & 5.05 & 5.20 \\
\hline Source: CGPJ
\end{tabular}

Source: CGPJ (2010) and self elaboration

to the courts in a specific year) were awaiting resolution while the courts were able to resolve just one. In the worst case, this amount was almost 10. As we may observe, there was, on average, a difference of 5.98 congestion points between the most efficient and the least efficient province throughout the period.

Figure 1 represents this quotient for the years 2001 and 2007. A decrease in the efficacy of the system can be observed throughout the period. Looking at the graph, it is also clear that no specific provincial pattern seems to emerge in the reduction of the efficacy of the judicial system. However, the Basque Country has a better performance over the entire period.

Note that Law 19/2009 (see Sect. 1) introduced several minor changes to the procedures of the CPL. These reforms can be summarized as follows: First, it generalized the use of a specific type of procedure (juicio verbal) to resolve all eviction-related conflicts. Secondly, it removed some of the options that the tenant had to hinder the declaratory judgment. Finally, it accelerated the execution of the declaratory judgments. These changes could accelerate the functioning of the judicial system, improving the figures discussed above. However, there is still no data available in order to analyze those effects.

What was the evolution of the property rate during this period (2001-2007)? The proportion of property among the total number of primary dwellings in Spain (called "Prprop" in the tables) is in fact chosen as a dependent variable in this research. That proportion is the aggregate counterpart of the individual housing tenure decision. The data are obtained from the Spanish Ministry of Housing (2008) and are available for the period 2001-2007 for 50 Spanish provinces (excluding Ceuta and Melilla). ${ }^{14}$ This classification divides the primary residences into three groups: dwellings in the property market, dwellings in the tenancy market, and "transferred dwellings" (cessions or non-profitable use of the houses). On average, in $2007,88.2 \%$ of the dwellings were

\footnotetext{
14 Note that the data is provided in November of each year and not in January. That fact is taken into account in the estimations.
} 


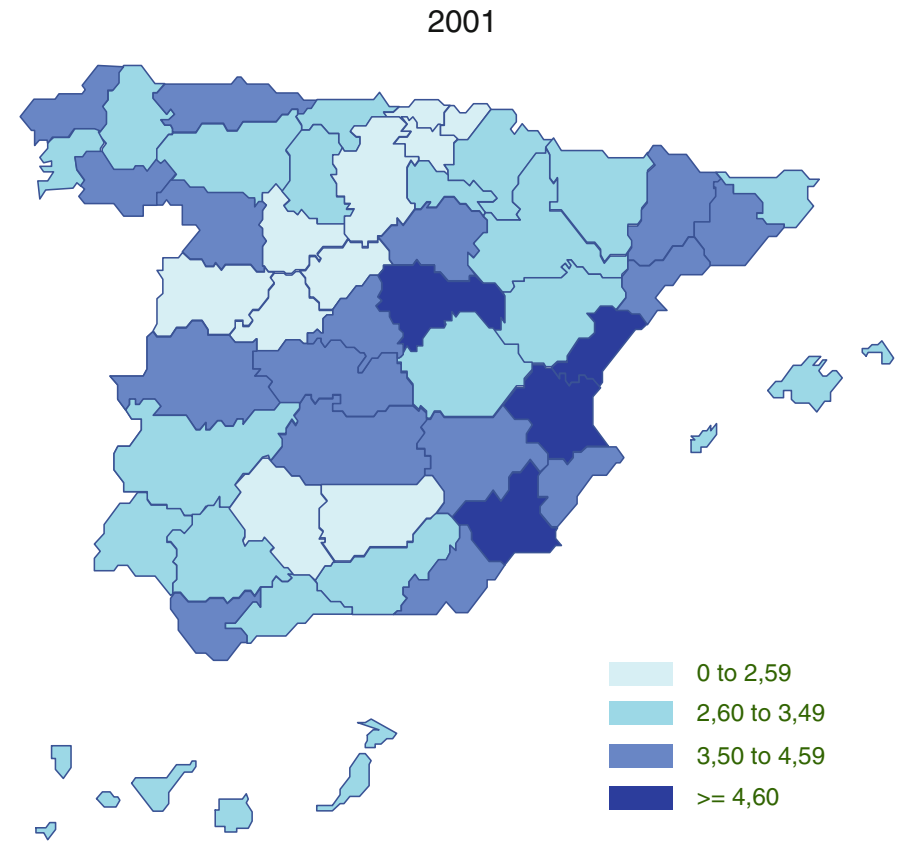

2007
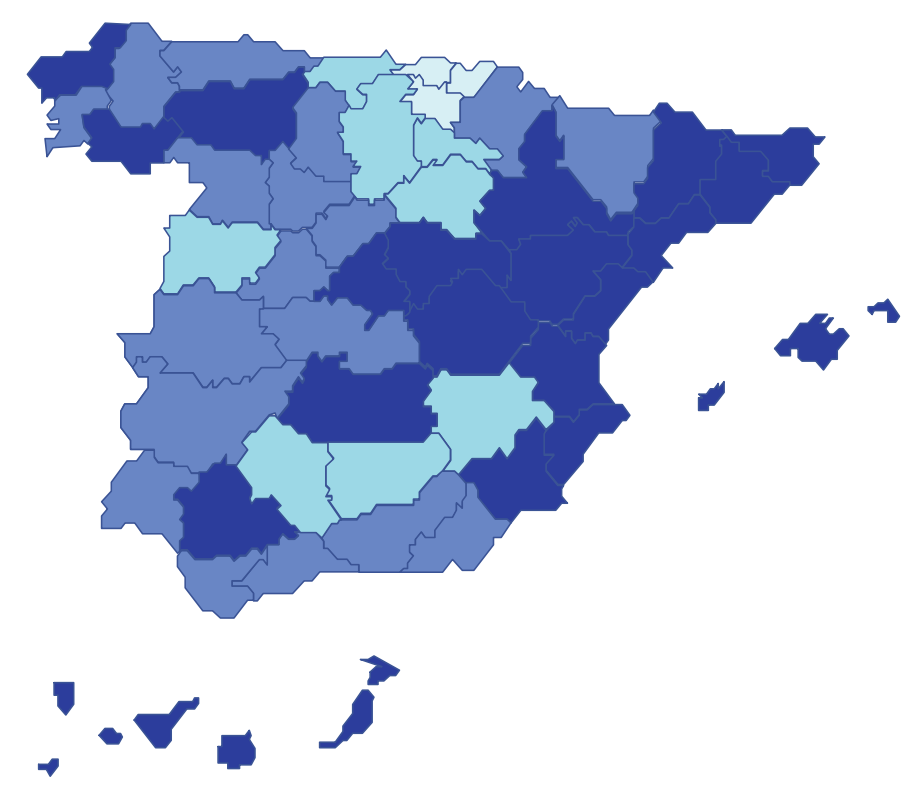

Fig. 1 Congestion rate (executory stage) 
in the property market, $9.8 \%$ were in the tenancy market and $1.9 \%$ were "transferred houses" (cessions).

On average, the share of property in the Spanish economy is very high (with a mean of $88.6 \%$ over the whole period) although some strong differences can still be found among provinces (share below $80 \%$ in the Balearic Islands, Las Palmas, Girona or Barcelona over several years and above $94 \%$ in Lugo, Soria or Castellón at the end of the period). Thus, there is some ground to explain and exploit inter-provincial differences. Table 3 presents the property shares between 2001 and 2007.

Moreover, some strong dynamics can be found at a provincial level. The province with the highest proportion of property in 2007 was $3.9 \%$ higher than the equivalent in 2001. More importantly, it should be noted that there is a difference of at least $14 \%$ during this period between the province with a higher proportion of property and that with the smaller one. Thus, some local factors may be affecting the provincial markets that differ from those identified at an aggregate level.

The aim of this paper is to test econometrically (taking into account all the usual controls analyzed and identified in the literature) if any significant relation exists between an increasing rate of inefficacy in the judicial system and the observed increase in the property share in the period analyzed. An increase in that proportion is expected if, ceteris paribus, the judicial system becomes more ineffective, that is, if the institutional environment for renting becomes more problematic.

\section{Modeling the effects of institutions on housing tenure outcomes}

\subsection{Empirical literature review}

The literature identifies a wide group of socio-economic factors such as the permanent income of individuals, the relative price of buying versus renting (or the user cost), financial restrictions, taxation and some demographic variables. ${ }^{15}$ Those factors affect the decision to buy or rent a dwelling (from the point of view of a potential tenant or a potential buyer) or the decision to place a property on the rental market (from the perspective of a potential landlord).

Although all the determinants affecting one side of the market will have an effect on the equilibrium share of property or tenancy of the economy, some studies distinguish those factors as mainly "demand factors" or "supply" factors (affecting the decisions of landlords more directly). Other determinants, such as prices, would affect both sides of the contracts at the same time and should be treated as endogenous.

This subsection aims to provide a limited survey of both the empirical literature and the most studied variables affecting the housing tenure choice. Special attention is paid to the "demand" or "supply" considerations studied.

Firstly, several works discussed the effect of pure demographic factors such as the proportion of young people or married couples in the population on the share of property of the economy (as an outcome of the housing tenure choice) (see Jaffe and Rosen

\footnotetext{
15 Other factors cited in the introduction, such as the tenancy laws, are not studied in the remainder of this paper as they will not introduce any inter-regional variation to exploit in the estimations.
} 
Table 3 Share of property in the Spanish provinces

\begin{tabular}{|c|c|c|c|c|c|c|c|}
\hline Province & 2001 & 2002 & 2003 & 2004 & 2005 & 2006 & 2007 \\
\hline Álava & 91.65 & 91.27 & 90.61 & 90.22 & 89.73 & 89.31 & 88.63 \\
\hline Albacete & 88.47 & 89.59 & 90.48 & 91.25 & 92.06 & 92.82 & 92.82 \\
\hline Alicante & 89.04 & 89.50 & 89.98 & 90.41 & 90.80 & 91.36 & 91.36 \\
\hline Almería & 85.60 & 86.26 & 87.13 & 88.19 & 88.97 & 89.79 & 89.79 \\
\hline Ávila & 90.61 & 91.28 & 91.91 & 92.58 & 93.22 & 93.84 & 93.84 \\
\hline Badajoz & 86.17 & 87.09 & 87.83 & 88.48 & 89.14 & 89.74 & 89.74 \\
\hline Baleares & 77.37 & 78.41 & 79.76 & 81.16 & 82.21 & 82.91 & 82.91 \\
\hline Barcelona & 80.88 & 80.42 & 80.12 & 80.14 & 79.94 & 79.91 & 79.91 \\
\hline Burgos & 89.29 & 89.01 & 88.91 & 88.79 & 88.89 & 88.76 & 88.76 \\
\hline Cáceres & 85.47 & 86.30 & 87.41 & 88.20 & 89.06 & 89.82 & 89.82 \\
\hline Cádiz & 83.27 & 83.43 & 83.85 & 84.44 & 84.91 & 85.22 & 85.22 \\
\hline Castellón & 89.01 & 90.17 & 91.20 & 92.29 & 93.27 & 94.44 & 94.44 \\
\hline Ciudad Real & 89.68 & 90.15 & 90.71 & 91.08 & 91.62 & 92.59 & 91.95 \\
\hline Córdoba & 88.73 & 89.27 & 89.83 & 90.35 & 91.10 & 91.67 & 91.67 \\
\hline A Coruña & 84.79 & 85.46 & 86.18 & 87.05 & 87.69 & 88.20 & 88.20 \\
\hline Cuenca & 91.32 & 90.66 & 89.97 & 89.33 & 88.86 & 88.29 & 88.29 \\
\hline Girona & 82.46 & 81.95 & 81.55 & 80.33 & 79.45 & 78.85 & 78.85 \\
\hline Granada & 86.43 & 87.42 & 87.99 & 88.74 & 89.54 & 90.05 & 90.05 \\
\hline Guadalajara & 90.60 & 91.08 & 91.40 & 91.91 & 92.36 & 92.75 & 92.75 \\
\hline Guipúzcoa & 90.12 & 89.55 & 88.90 & 88.36 & 88.12 & 87.58 & 87.58 \\
\hline Huelva & 87.46 & 88.16 & 89.11 & 89.90 & 90.51 & 91.19 & 91.19 \\
\hline Huesca & 88.49 & 88.47 & 88.30 & 88.21 & 87.88 & 87.33 & 87.33 \\
\hline Jaén & 89.20 & 89.98 & 90.84 & 91.60 & 92.49 & 93.25 & 93.25 \\
\hline León & 85.39 & 86.14 & 86.71 & 87.27 & 87.78 & 88.38 & 88.38 \\
\hline Lleida & 85.78 & 87.52 & 89.03 & 90.34 & 91.58 & 92.71 & 92.71 \\
\hline La Rioja & 88.78 & 89.52 & 90.40 & 90.97 & 91.38 & 91.99 & 91.99 \\
\hline Lugo & 90.69 & 91.85 & 92.78 & 93.74 & 94.66 & 95.58 & 95.58 \\
\hline Madrid & 84.49 & 84.24 & 83.91 & 83.62 & 83.13 & 83.37 & 83.06 \\
\hline Málaga & 86.25 & 86.09 & 85.77 & 85.73 & 85.69 & 87.24 & 85.53 \\
\hline Murcia & 88.01 & 88.67 & 89.30 & 90.10 & 90.81 & 91.54 & 91.54 \\
\hline Navarra & 90.14 & 90.67 & 91.42 & 92.08 & 92.66 & 93.17 & 93.17 \\
\hline Ourense & 90.03 & 89.20 & 88.61 & 87.78 & 87.16 & 86.51 & 86.50 \\
\hline Asturias & 84.49 & 85.08 & 85.46 & 85.92 & 86.25 & 86.71 & 86.71 \\
\hline Palencia & 88.78 & 89.36 & 89.89 & 90.55 & 91.33 & 91.95 & 91.93 \\
\hline Las Palmas & 78.30 & 78.96 & 80.02 & 80.58 & 80.75 & 81.47 & 81.47 \\
\hline Pontevedra & 85.94 & 85.58 & 85.48 & 85.89 & 86.20 & 85.87 & 86.19 \\
\hline Salamanca & 88.85 & 89.30 & 89.73 & 90.30 & 90.85 & 91.33 & 91.33 \\
\hline Santa Cruz de Tenerife & 81.45 & 82.08 & 82.90 & 83.34 & 83.86 & 84.58 & 84.58 \\
\hline Cantabria & 88.90 & 89.29 & 89.85 & 90.29 & 90.98 & 91.36 & 91.36 \\
\hline Segovia & 87.75 & 87.96 & 87.86 & 87.97 & 87.69 & 87.96 & 87.96 \\
\hline
\end{tabular}


Table 3 continued

\begin{tabular}{llllllll}
\hline Province & 2001 & 2002 & 2003 & 2004 & 2005 & 2006 & 2007 \\
\hline Sevilla & 89.08 & 89.05 & 88.81 & 88.48 & 88.35 & 88.66 & 88.04 \\
Soria & 89.48 & 90.74 & 92.04 & 93.24 & 94.35 & 95.36 & 95.36 \\
Tarragona & 86.06 & 87.05 & 87.93 & 88.87 & 89.41 & 90.22 & 90.22 \\
Teruel & 89.35 & 90.25 & 91.14 & 92.20 & 93.18 & 94.00 & 94.00 \\
Toledo & 90.02 & 90.55 & 91.23 & 91.83 & 92.31 & 92.79 & 92.79 \\
Valencia & 89.79 & 90.16 & 90.44 & 90.68 & 90.93 & 91.21 & 91.21 \\
Valladolid & 88.56 & 89.22 & 89.64 & 90.02 & 90.46 & 90.90 & 90.90 \\
Vizcaya & 91.55 & 91.81 & 92.33 & 92.71 & 93.23 & 93.50 & 93.50 \\
Zamora & 90.82 & 91.29 & 91.86 & 92.36 & 92.83 & 93.27 & 93.27 \\
Zaragoza & 85.86 & 87.05 & 87.37 & 87.56 & 87.67 & 87.91 & 87.91 \\
\hline Source: Minitry
\end{tabular}

Source: Ministry of Housing of Spain (2008) and self elaboration

1979 or Green 1996). We would expect the tenancy rate to be positively related to the proportion of young people in the population but negatively related to an increase in the share of married couples. Following the same references, those factors are usually identified as "demand" factors. In fact, the age of a landlord has not been a point of discussion in the same research.

In turn, another demographic factor, the population density, would mainly affect the decisions of landlords (the supply side) and not tenants. Linneman (1986) argues that landlords face reduced costs of monitoring and higher efficiency in supplying housing services in the case of highly populated towns. Thus, we would expect to find a negative relation between home ownership and population density on the landlord's side (also Fisher and Jaffe 2003).

The effect of wealth in the house tenure decision is also widely studied in the literature (De Leeuw and Ekanem 1971; Haurin et al. 1996). Several studies have found that, among other factors, the rate of home ownership is positively related to GDP per capita or similar income measures (reducing the demand for tenancy), although that relation is not always significant (Fisher and Jaffe 2003).

Credit constraints and financial capacity are also determinants of the tenancy or property share observed in the economy. They mainly affect the tenant/buyer side as the financial constraint will prevent some tenants from buying a property (Jaffe and Rosen 1979; Hargreaves 2003; Lauridsen and Skak 2007; Mayordomo 2008). In fact, this effect may be coincident with age, as younger individuals may face higher constraints because their actual income is much lower than their future earnings (Lafayette et al. 1995).

Finally, the price of renting versus buying affects both sides of a tenancy contract (or a home purchase agreement). In other words, the "price" can be understood as the outcome of the contracts in the market. In any case, the higher the price of buying a home (compared to the price of renting a dwelling), the higher the number of individuals who will choose to rent. The opposite argument would hold for the other side of the contract (the landlord/seller). The measure of "prices" takes very different forms in 
the literature: some works have estimated the effect of rental prices (Jaffe and Rosen, 1979), while others have opted for relative measures. For instance, Hendershott and Shilling (1980) studied the effect of the relative cost of owner-occupied dwellings and rental prices. In turn, Rodríguez and Barrios (2004) and Barrios García and Rodríguez Hernández (2004) calculated a user cost taking into account both the prices of buying and of renting and some related fiscal issues. Several types of public intervention, such as fiscal incentives or the provision of public housing, may play a significant role as well (Rosen 1979; Rosen and Rosen 1980; Lauridsen and Skak 2007).

Thus, in general, while the demand for housing services is directly driven by a group of heterogeneous factors ranging from demography to wealth, the supply side (landlords and sellers) is mainly affected by the interaction with costs, frictions and prices (derived from some heterogeneous factors such as the user cost of the properties, the actual relative prices of selling versus renting, the population density or the regulatory measures introduced by the tenancy laws). If more frictions are suffered in the tenancy market, some landlords will decide to quit the tenancy market.

In this context, one extra "cost" that a landlord faces, and which has not been studied in the literature cited above, is "judicial inefficacy". Judicial inefficacy can be considered then as an exogenous variable affecting the equilibrium price (together with the quantity of housing services in the market) affecting the equilibrium through movements in the supply curve. Section 3.2 provides a theoretical framework for that argument.

\subsection{Theoretical background}

To integrate all of the reasoning set out in this paper, it seems useful to discuss how agents (on the demand or supply side of the market) behave in theoretical terms when they are faced with the housing tenure choice. Moreover, it is useful to examine, in that same theoretical context, how those agents behave when they are confronted with an ineffective judicial system.

Henderson and Ioannides (1983) offer a useful model for this issue as they study the behavior of both owner-occupiers and renters through their decisions to consume and invest in housing services. If the investment demand for housing is sufficiently large relative to consumption demand, the individual will own a dwelling and will rent part of the free space in the housing market. Thus, he will be a landlord offering housing services. On the contrary, if the consumption demand is larger than the investment demand, the individual will choose to rent and will not own a house (we will observe him as a tenant consuming housing services but not investing).

In the model, the housing consumption demand will depend on several factors such as wealth, the income path or financial restrictions. For instance, an individual with less wealth at the beginning of his lifetime will be a tenant if he is also confronted with financial restrictions.

It is even more relevant to observe how the investment side works. If the profitability of investing in housing diminishes, less "space" will be offered in the market (that is to say, the number of "landlords" will diminish in the economy). In fact, the profitability of the investment in housing services is affected by several factors such 
as maintenance costs, taxation or depreciation. This paper studies the effects on the market of a very specific transaction cost: the judicial "inefficacy" which exclusively affects landlords.

As noted in the introduction, the decision to place a dwelling on the rental market implies some transaction costs (basically the enforcement of the contract over time). In other words, renting implies the establishment of a long-term relationship with another agent in the market (the tenant) and involving some risk (and therefore some enforcement costs over time, such as the use of the judicial system). From a theoretical point of view, the implication of an increased transaction cost is that increased legal costs reduce the profitability of "investing" in housing, so some agents decide to put less "space" in the rental market.

Following Henderson and Ioannides (1983), individuals maximize the following multi-period utility function:

$$
U\left(x, f(u) h_{c}\right)+V(w)
$$

where $U$ stands for the utility obtained from the consumption bundle, $V(w)$ stands for the indirect utility function of wealth remaining after period 1 and the function $f$ has the following properties: $f^{\prime}(u)>0$ and $f^{\prime \prime}(u)<0$. The services obtained from a house (as a durable good) are determined by $u$ (the rate of utilization) and $h$ (the capacity). $x$ stands for the consumption in period 1 of the numéraire.

If the individual is an owner, he will maximize the utility function subject to the following constraints:

$$
\begin{aligned}
y_{1} & =x+P h_{c}+S \\
w & =y_{2}+S(1+r)+P h_{c}-T(u) h_{c}
\end{aligned}
$$

where $T(u)$ is the utilization cost function, $y$ represents income, $P$ is the market purchase price of a unit of housing stock, $S$ is savings and $r$ is the rate of interest.

If the individual is a tenant, the constraints he faces are the following:

$$
\begin{aligned}
y_{1} & =x+R h_{c}+S \\
w & =y_{2}+S(1+r)-\tau(u) h_{c}
\end{aligned}
$$

where $R$ stands for the rental price of housing and $\tau(u)$ is the tenant cost function.

To introduce judicial inefficacy $(J)$ in the model of Henderson and Ioannides (1983), I could model the utilization cost function of the dwelling as:

$$
T(u)=\alpha J u^{2}
$$

$J$ will increase the transaction costs for the landlord. Four different ways to measure $J$ are explained in Sect. 2 and Appendix A. In any case, the judicial inefficacy $(J)$ will take always positive values. $\alpha$ is a parameter and $u$ is the rate of utilization. As required, $T(u)$ is a convex function: $T^{\prime}(u)>0$ and $T^{\prime \prime}(u)>0$. 
On the other hand, the tenant cost function could take the following simple form that does not depend on the judicial efficiency:

$$
\tau(u)=u^{2}
$$

where $\tau(u)$ is also a convex function. $\tau^{\prime}(u)>0$ and $\tau^{\prime \prime}(u)>0$.

With those two cost functions, the equilibrium condition of the HendersonIoannides model will take the following form:

$$
\frac{r P}{1+r}=R-\frac{u^{2}[\alpha J-1]}{1+r}
$$

That is,

$$
u=\sqrt{\frac{R(1+r)-r P}{\alpha J-1}}
$$

where, $\frac{\partial u}{\partial J}<0, \frac{\partial u}{\partial R}>0, \frac{\partial u}{\partial r}<0$ and $\frac{\partial u}{\partial P}<0$, if $1-\alpha J>0$.

Thus, following that derivation, in equilibrium the rate of utilization will depend negatively on the judicial inefficacy. As previously stated, judicial inefficacy can be understood as a cost for the landlord. As a result, if judicial costs increase, less "space" will be put into the tenancy market (and thus, theoretically, we would observe a less developed tenancy market). Another theoretical argument about how agents behave when they confront a risk of non-payment of rent can be found in Casas-Arce and Saiz (2010).

$$
u=g(\underline{J}, \underline{r}, \underset{+}{R}, \underline{P})
$$

Even though we consider $J$ and $r$ as exogenous variables affecting the equilibrium, $R$ and $P$ (together with the quantity of housing services in the market) are defined within the model. In an econometric implementation they should therefore be treated as endogenous and thus they must be instrumented. For instance, an exogenous shock increasing judicial inefficacy will affect the equilibrium price and the quantity of housing services through a shift in the supply side (or investment) of housing services but not through the demand curve as defined before. Thus, in the case of an econometric estimation of the supply curve, we will have to instrument the price (or the user cost) using for instance strictly "demand" instruments (that is, demand shifters which are not affecting the supply).

\section{Empirical strategy}

\subsection{Model}

The objective of this research is to offer estimations of the effect of the inefficacy of the judicial system on the proportion of property in the economy. As discussed above, 
judicial inefficacy can be understood as an extra cost that landlords face when they rent their properties in the market. Therefore, following the reasoning offered in Sect. 3, I propose to estimate a supply curve.

Then, the following model is proposed (Eq. 2):

$$
\begin{aligned}
\text { Prprop }_{\mathrm{i}, \mathrm{t}}=\mathrm{c} & +\sum \mathrm{c}_{\mathrm{t}} \mathrm{T}_{\mathrm{t}}+\beta_{1} \text { Usercost }_{\mathrm{i}, \mathrm{t}}+\beta_{2} \text { Excongestion }_{\mathrm{i}, \mathrm{t}}+\beta_{3} \text { Density }_{\mathrm{i}, \mathrm{t}} \\
& +\left(\eta_{\mathrm{i}}+v_{\mathrm{i}, \mathrm{t}}\right)
\end{aligned}
$$

$\beta_{2}$ is the effect of judicial inefficacy ("excongestion" in this setup), on the share of property, "prprop". As previously discussed, we expect that the population density, "density", is negatively related to the property share. The price should enter the equation with a positive sign as we are estimating a supply curve. A detailed description of the variables used in this study is provided in Table 4.

The measure of judicial inefficacy could be affected by the litigation in the province. In order to provide results that take this possibility into account, alternative estimates including a measure of "litigation" by province are provided in this paper. "Litigation" is approximated by the number of lawyers per capita, "Lawyerspc" (see for instance, Carmignani and Giacomelli 2010). In that case, the model takes the following form (Eq. 3):

$$
\begin{aligned}
\text { Prprop }_{\mathrm{i}, \mathrm{t}}=\mathrm{c} & +\sum \mathrm{c}_{\mathrm{t}} \mathrm{T}_{\mathrm{t}}+\beta_{1} \text { Usercost }_{\mathrm{i}, \mathrm{t}}+\beta_{2} \text { Excongestion }_{\mathrm{i}, \mathrm{t}} \\
& +\beta_{3} \text { Lawyerspc }_{\mathrm{i}, \mathrm{t}}+\beta_{4} \text { Density }_{\mathrm{i}, \mathrm{t}}+\left(\eta_{\mathrm{i}}+v_{\mathrm{i}, \mathrm{t}}\right)
\end{aligned}
$$

The "price" (taking the form of a user cost, "usercost") will be an endogenous variable as we face a simultaneity problem. That is, the price and quantity are jointly determined by the demand and supply curves of the market. Thus, I will instrument the price using several demand shifters.

I choose as instruments a set of variables directly affecting the demand side of the market: the proportion of young people in the province, ppob2039 and its lagged value, the proxy to credit constraint, credit and its lagged value, the lagged value of income per capita, $\ln G D P p c$, and the proportion of social housing in the province, Shousing. Also the lagged user cost will be included as an instrument. As explained in Table 4, the measure "credit" takes account of the effects on mortgage lending implied by the inefficacy of the judicial system when solving mortgage conflicts. To choose the set of instruments and provide evidence of their validity, the Hansen J statistic (as over-identification test) is computed with satisfactory results in all cases. ${ }^{16}$ Note that, in general, the strategy of including the lagged dependent variables of Eq. 1 (or 2) as instruments has been avoided (thus providing a more robust experiment).

Following Sect. 2, judicial efficacy has been studied at both stages of the procedure (declaratory and execution) in the form of a congestion rate. Prtcongestion and excongestion enter the equation lagged several periods, up to four, taking into account that the decision to put a dwelling into the tenancy market may take into account the "judicial environment" observed some periods before. This fact would

$\overline{16}$ Note that I did not assume homoskedasticity. Otherwise, the Sargan's statistic would be reported. 


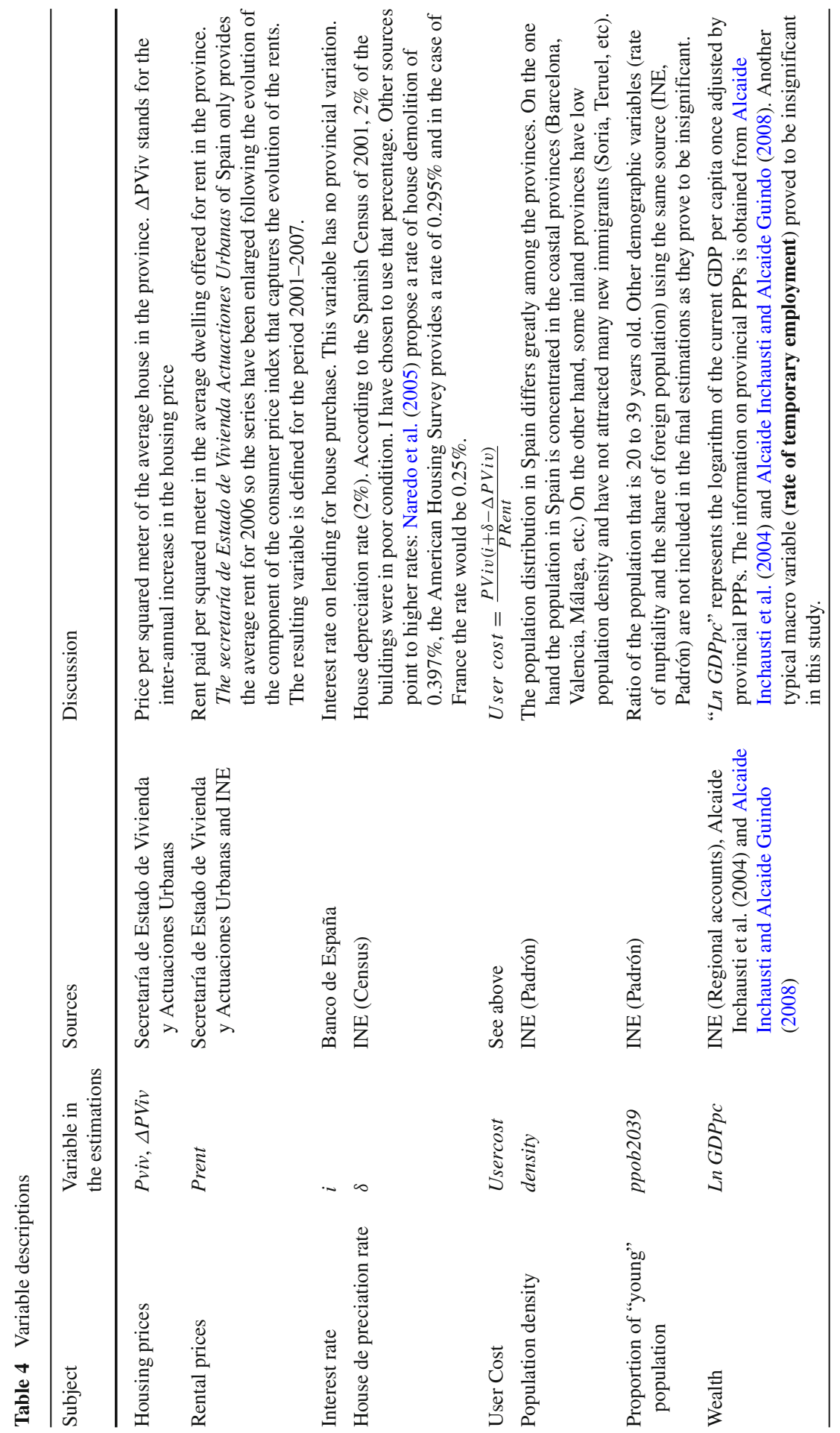




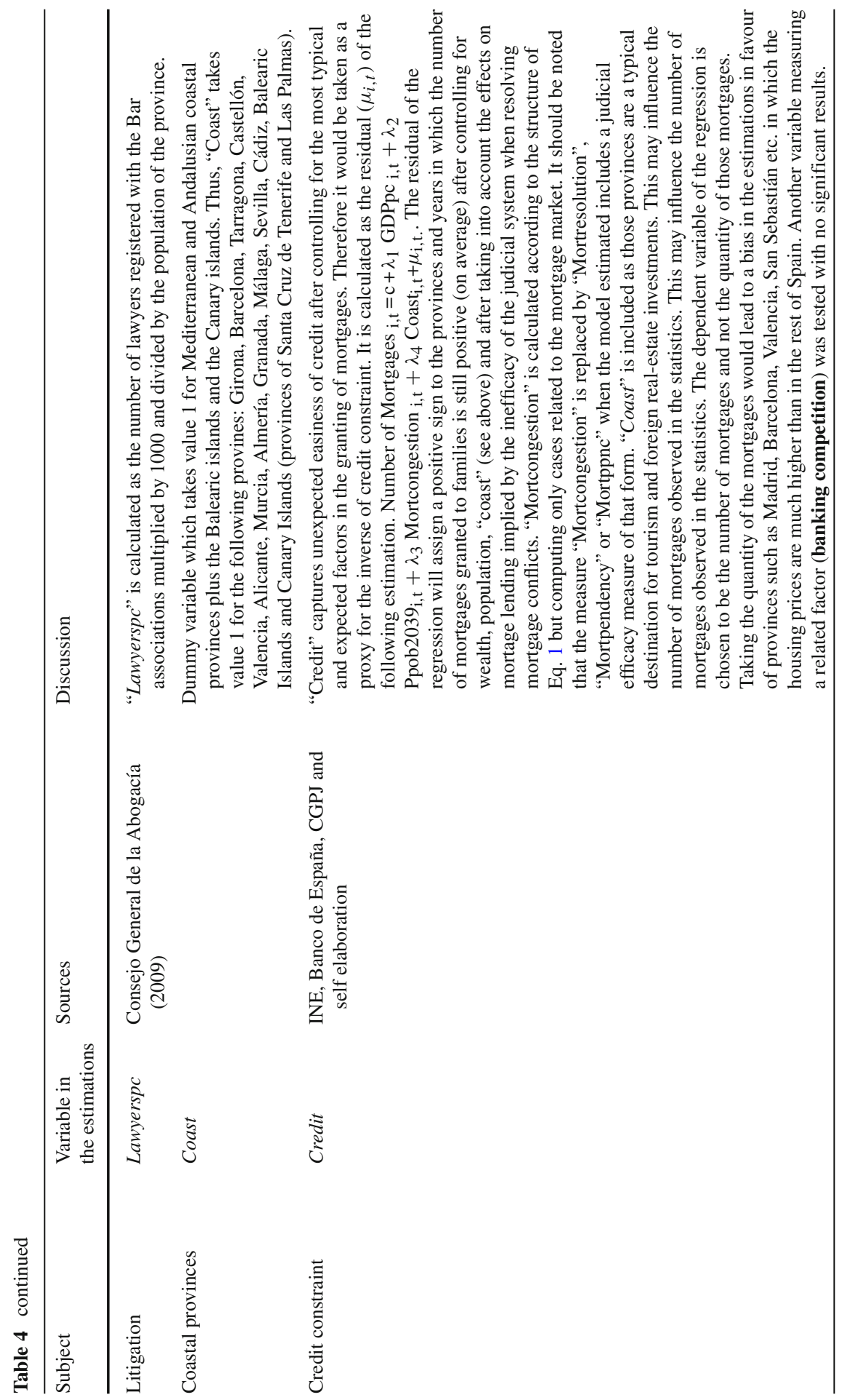




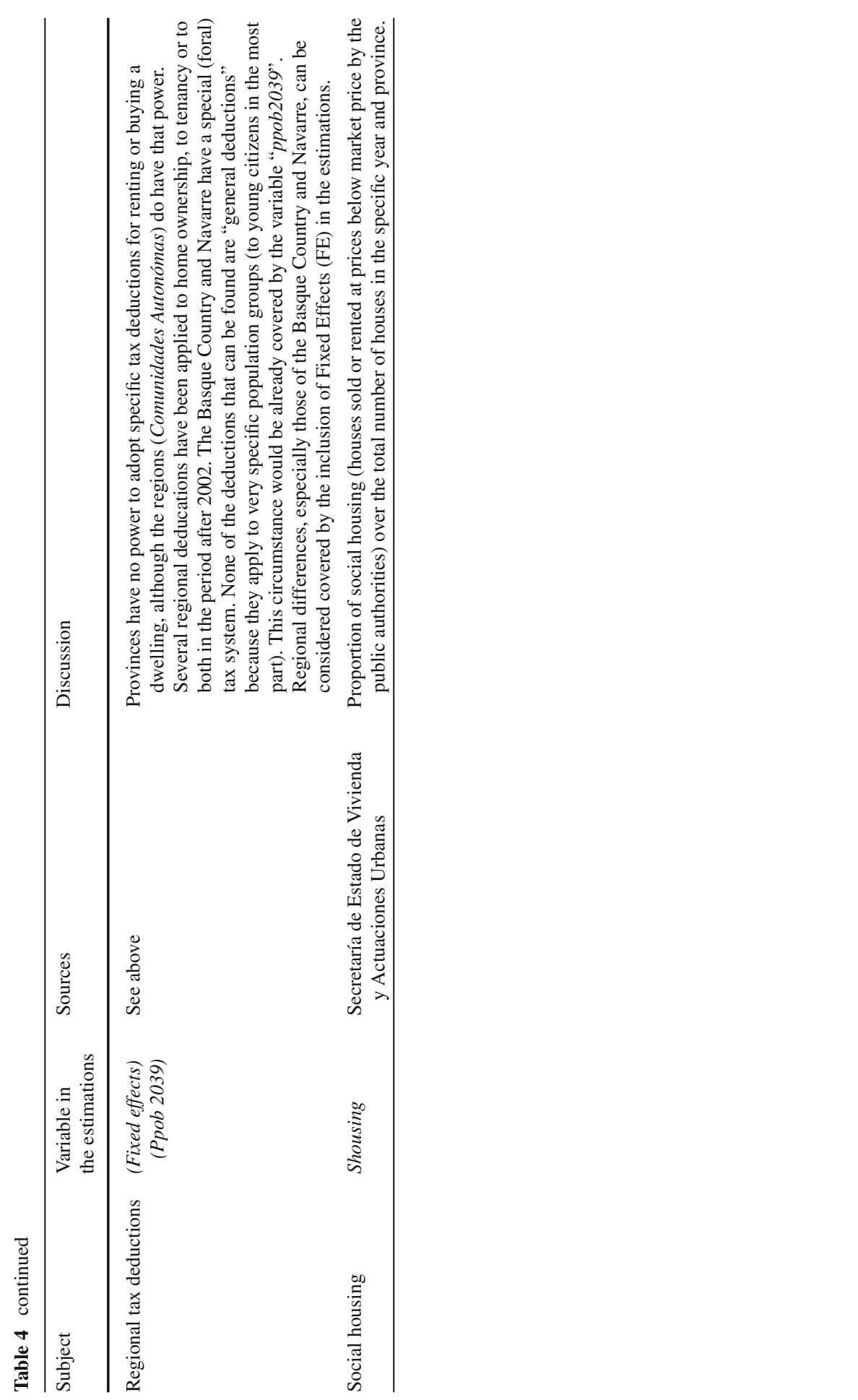


also mitigate any problems of endogeneity of the judicial variables. In any case, there are no reasons to suspect the endogeneity of the judicial variables in this research. The courts considered in this study ("juzgados de primera instancia" and "juzgados de primera instancia e instruccion") are not specialized courts and resolve a wide range of conflicts, from inheritance conflicts to bankruptcy proceedings. Thus the distribution of tenancy conflicts (generated in part by the amount of tenancy and property contracts in the province) is not necessarily influencing the distribution of "juzgados de primera instancia" and "juzgados de primera instancia e instrucción". Judges in Spain are also obliged to process and resolve cases in chronological order of entry, and therefore cannot give preference to a specific type of conflict.

The model is estimated following a two-step (instrumental variables) generalized method of moments (GMM estimation) (Woorldridge 2001; Arellano 2002; Baum et al. 2003). ${ }^{17}$

Fixed effects (FE) are included in all the estimations. Standard errors are clustered in order to make them robust to both heteroskedasticity and serial correlation. Time dummies are also included to take the cycle into account. Wald tests of significance for those time dummies are reported in the tables. Table 5 reports the results when estimating both Eq. 2 (models 1 and 2 in the Table) and Eq. 3 (models 3 and 4 in the Table).

\subsection{Results}

As an initial result, it is important to note that the efficacy of the declaratory stage has no significant impact on the share of property. ${ }^{18}$ Therefore, this paper focuses its analysis on the final or definitive step (execution). Nevertheless, this is an interesting result in and of itself, as will be discussed in the conclusions.

First of all, it is worth noting that the user cost (Table 5) enters the equation with a positive sign. The sign confirms that we have estimated a supply curve once we take into account that the over-identification tests were passed satisfactorily.

The variable density has the expected (negative) sign in all cases and is significant at 5 or $1 \%$ level.

Finally, looking at the results for the judicial variables, we find the expected effects. First of all, it is found that a higher congestion rate, that is, a lower efficacy of the judicial system, attracts more houses to the property market. That is to say that a "problematic" tenancy market prevents the owners/landlords from placing their dwellings on the tenancy market.

Table 5 shows that an increase in one point in the congestion rate would increase the share of property by around $0.14-0.16$ percentage points. Thus, taking the example of Madrid, the decrease in the congestion rate would attract around 3,400 dwellings to the rental market. In Barcelona, the increase would be around 3,100 dwellings and

\footnotetext{
17 Under the presence of heteroskedasticity, GMM estimators are more efficient than IV-robust ones.

18 The estimations are available on demand.
} 
Table 5 Effects of the judicial congestion rate

\begin{tabular}{|c|c|c|c|c|}
\hline $\begin{array}{l}\text { Model } \\
\text { Method of estimation } \\
\text { Data transformation }\end{array}$ & $\begin{array}{l}1 \\
2 \text {-Step GMM } \\
\text { FE }\end{array}$ & $\begin{array}{l}2 \\
\text { 2-Step GMM } \\
\text { FE }\end{array}$ & $\begin{array}{l}3 \\
\text { 2-Step GMM } \\
\text { FE }\end{array}$ & $\begin{array}{l}4 \\
\text { 2-Step GMM } \\
\text { FE }\end{array}$ \\
\hline Excongestion (t-3) & $\begin{array}{l}0.14 \\
0.05^{* * *}\end{array}$ & & $\begin{array}{l}0.13 \\
0.043 * * *\end{array}$ & \\
\hline Excongestion (t-4) & & $\begin{array}{l}0.16 \\
0.07 * *\end{array}$ & & $\begin{array}{l}0.16 \\
0.07 * *\end{array}$ \\
\hline User cost & $\begin{array}{l}0.07 \\
0.03 * *\end{array}$ & $\begin{array}{l}0.04 \\
0.03\end{array}$ & $\begin{array}{l}0.07 \\
0.03 * *\end{array}$ & $\begin{array}{l}0.04 \\
0.03\end{array}$ \\
\hline Density & $\begin{array}{l}-0.07 \\
0.02 * * *\end{array}$ & $\begin{array}{l}-0.05 \\
0.02 * *\end{array}$ & $\begin{array}{l}-0.07 \\
0.02 * * *\end{array}$ & $\begin{array}{l}-0.05 \\
0.02 * *\end{array}$ \\
\hline Lawyerspc (t-3) & & & $\begin{array}{l}1.00 \\
1.65\end{array}$ & \\
\hline Lawyerspc (t-4) & & & & $\begin{array}{l}0.93 \\
1.83\end{array}$ \\
\hline Time effects & Yes & Yes & Yes & Yes \\
\hline Observations & 250 & 200 & 250 & 200 \\
\hline Groups/Clusters & 50 & 50 & 50 & 50 \\
\hline Hansen $\mathrm{J}$ statistic ( $P$-value) & 0.85 & 0.89 & 0.80 & 0.87 \\
\hline Wald Test for time dummies & 0 & 0 & 0 & 0 \\
\hline
\end{tabular}

Dependent variable: Share of property

(Clustered) Standard errors robust to heteroskedasticity and serial correlation beneath coefficients Instrumented: User cost

Instruments: User cost (t-1), Ppop2039, Ppop2039 (t-1), Credit, Credit (t-1), In GDPpc (t-1). Shousing

$* * * \mathrm{p}<1 \%$

$* * \mathrm{p}<5 \%$

$* \mathrm{p}<10 \%$

in Valencia around 1,400 dwellings. ${ }^{19}$ Those results are significant at around 5 or $1 \%$ respectively. The variable "Lawyerspc" is insignificant and does not affect the results.

Appendix A provides a discussion of the results of the model when alternative measures of judicial efficiency are computed ("pending cases rate", "resolution rate" and the "pending-plus-new cases rate"). The results are consistent with those presented here.

\section{Conclusions}

This research presents some estimations of the effect of the efficacy of the judicial system on the proportion of property in the Spanish provinces. The problem is analyzed

\footnotetext{
19 An interesting experiment is to calculate how many dwellings, according to the model, would be won by the tenancy market of Madrid if the rate of congestion in Madrid improves to the level of the average congestion rate of the Basque Country in 2007. In that case, the increase in the number of dwellings for rent in Madrid would be between 9,600 and 12,100. The same experiment in the case of Barcelona would lead to an increase in rental housing of between 7,300 and 9,100 dwellings.
} 
econometrically through panel data techniques. Specifically, the generalized method of moments (2-step GMM) is used in the estimations as several instrumental variables are taken into account. This study is the first one in the economic literature to tackle the case of Spain at the local level.

The judicial efficacy is measured through the construction of a "congestion" indicator at two stages of the procedure: the declaratory stage and its final executory stage.

This research does not find any significant impact of judicial efficacy at the declaratory stage on the housing property share. However, this research concludes that an increase in judicial efficacy at the execution stage would have a positive, although minor, impact on the share of property in the Spanish provinces. The effect amounts to around 0.15 percentage points of the housing market (higher effects are found if other efficacy measures are taken into account) (see Appendix A). That effect would denote that homeowners avoid the tenancy market when they cannot enforce their contracts.

The discussions presented in this research give some grounds to improve the efficacy of the judicial system, at least at the execution stage, in order to develop the Spanish tenancy market. In this sense, future research based on this paper could evaluate the effects of the recent reforms of the tenancy market in Spain, introduced by Law 19/2009, when the relevant data is available.

\section{Appendix A: Estimations with alternative judicial efficacy measures}

Judicial efficacy can be measured in different ways. This paper has opted to study the "congestion rate", even though other efficacy measures could be computed.

This Appendix presents the results of the study if three alternative efficacy measures are taken into account: the "pending cases rate", the "resolution rate" and the "pending-plus-new cases rate". The pending cases rate is defined as the ratio between pending cases in a specific year and the cases resolved in the same period. The resolution rate is defined as the ratio between the cases resolved and the cases that entered the system for a specific year. Finally, the "pending-plus-new cases rate" (ppnc) is calculated as the sum of the new cases and the pending cases (measured at the beginning of the year), divided by the population of the province in that year (see equations grouped as 4).

$$
\begin{aligned}
& \text { Pending cases rate }_{i, t}=\frac{{\text { Pending } \text { cases }_{i, t}}_{\text {Cases resolved }}^{i, t}}{\text { Cases resolved }} \\
& \text { Re } \text { solution rate }_{i, t}=\frac{\text { Cases resolved }_{i, t}}{\text { New } \text { cases }_{i, t}} \\
& \text { Pending }- \text { plus }- \text { new cases rate } \text { Pet }_{t}=\frac{{\text { Pending } \text { cases }_{i, t}+\text { New }_{\text {cases }}, t}_{\text {Population }_{i, t}}}{\text { Popula }}
\end{aligned}
$$

As a measure, the "pending-plus-new cases rate" tries to take into account that the workload of the courts may vary due to the different populations of the provinces. 
Table 6 Effects of the judicial pendency rate

\begin{tabular}{|c|c|c|c|c|}
\hline $\begin{array}{l}\text { Model } \\
\text { Method of estimation } \\
\text { Data transformation }\end{array}$ & $\begin{array}{l}1 \\
2 \text {-Step GMM } \\
\text { FE }\end{array}$ & $\begin{array}{l}2 \\
\text { 2-Step GMM } \\
\text { FE }\end{array}$ & $\begin{array}{l}3 \\
2 \text {-Step GMM } \\
\text { FE }\end{array}$ & $\begin{array}{l}4 \\
2 \text {-Step GMM } \\
\text { FE }\end{array}$ \\
\hline Expendency (t-3) & $\begin{array}{l}0.18 \\
0.09^{*}\end{array}$ & & $\begin{array}{l}0.16 \\
0.08 * *\end{array}$ & \\
\hline Expendency (t-4) & & $\begin{array}{l}0.27 \\
0.13^{* *}\end{array}$ & & $\begin{array}{l}0.27 \\
0.14 * *\end{array}$ \\
\hline User cost & $\begin{array}{l}0.08 \\
0.03 * *\end{array}$ & $\begin{array}{l}0.06 \\
0.03^{*}\end{array}$ & $\begin{array}{l}0.07 \\
0.03 * *\end{array}$ & $\begin{array}{l}0.06 \\
0.03 *\end{array}$ \\
\hline Density & $\begin{array}{l}-0.07 \\
0.02 * * *\end{array}$ & $\begin{array}{l}-0.05 \\
0.02 * *\end{array}$ & $\begin{array}{l}-0.07 \\
0.02 * * *\end{array}$ & $\begin{array}{l}-0.05 \\
0.02 * *\end{array}$ \\
\hline Lawyerspc (t-3) & & & $\begin{array}{l}0.87 \\
1.73\end{array}$ & \\
\hline Lawyerspc (t-4) & & & & $\begin{array}{l}0.51 \\
1.95\end{array}$ \\
\hline Time effects & Yes & Yes & Yes & Yes \\
\hline Observations & 250 & 200 & 250 & 200 \\
\hline Groups/Clusters & 50 & 50 & 50 & 50 \\
\hline Hansen J statistic (P-value) & 0.73 & 0.81 & 0.70 & 0.82 \\
\hline Wald Test for time dummies & 0 & 0 & 0 & 0 \\
\hline
\end{tabular}

Dependent variable: Share of property

(Clustered) Standard errors robust to heteroskedasticity and serial correlation beneath coefficients Instrumented: User cost

Instruments: User cost (t-1), Ppop2039, Ppop2039 (t-1), Credit, Credit (t-1), In GDPpc (t-1), Shousing $* * * \mathrm{p}<1 \%$

$* * \mathrm{p}<5 \%$

$* \mathrm{p}<10 \%$

A higher "resolution rate" and a lower "pending cases rate" are related to greater efficacy of the judicial system. A higher "pending-plus-new cases rate" is again a proxy of congestion of the judicial system (although related to the population of the province) and therefore it can be expected that a higher workload per capita is related to a lower efficacy. Some summary statistics are included in Table 1.

With respect to the first measure of efficacy related to executions, expendency, we can observe the following: On average (see Table 1), almost three times more cases were pending (waiting to be resolved) in the execution stage with respect to the cases that the courts were able to solve. Although some provinces had, on average, very good results (pendency rate of 0.46), other provinces had more than seven times more cases waiting to be resolved than the average workload they were able to resolve in a year.

With respect to the resolution rate, we can say that, on average, the judicial system was able to resolve nearly the same amount of cases as were entering the courts (resolution rate of 0.87 ) at the execution stage. This does not imply a constant workload because some conflicts may be waiting on the list at the beginning of the year (this aspect is better analyzed with more complete measures of efficacy as the pendency cases rate and the congestion rate). Even though some provinces underperformed quite radically (minimum of 0.42 ), others were able to resolve two times more cases than the 
Table 7 Effects of the judicial resolution rate

\begin{tabular}{|c|c|c|c|c|}
\hline $\begin{array}{l}\text { Model } \\
\text { Method of estimation } \\
\text { Data transformation }\end{array}$ & $\begin{array}{l}1 \\
2-\text { Step GMM } \\
\text { FE }\end{array}$ & $\begin{array}{l}2 \\
\text { 2-Step GMM } \\
\text { FE }\end{array}$ & $\begin{array}{l}3 \\
\text { 2-Step GMM } \\
\text { FE }\end{array}$ & $\begin{array}{l}4 \\
\text { 2-Step GMM } \\
\text { FE }\end{array}$ \\
\hline Exresolution (t-3) & $\begin{array}{l}-0.03 \\
0.31\end{array}$ & & $\begin{array}{l}-0.01 \\
0.29\end{array}$ & \\
\hline Exresolution (t-4) & & $\begin{array}{l}-0.82 \\
0.32 * *\end{array}$ & & $\begin{array}{l}-0.88 \\
0.34 * *\end{array}$ \\
\hline User cost & $\begin{array}{l}0.07 \\
0.03 * *\end{array}$ & $\begin{array}{l}0.07 \\
0.02 * * *\end{array}$ & $\begin{array}{l}0.06 \\
0.03 * *\end{array}$ & $\begin{array}{l}0.07 \\
0.02 * * *\end{array}$ \\
\hline Density & $\begin{array}{l}-0.07 \\
0.02 * * *\end{array}$ & $\begin{array}{c}-0.05 \\
0.02 * *\end{array}$ & $\begin{array}{l}-0.07 \\
0.02 * * *\end{array}$ & $\begin{array}{l}-0.06 \\
0.02 * *\end{array}$ \\
\hline Lawyerspc (t-3) & & & $\begin{array}{l}1.42 \\
1.88\end{array}$ & \\
\hline Lawyerspc (t-4) & & & & $\begin{array}{l}1.35 \\
1.86\end{array}$ \\
\hline Time effects & Yes & Yes & Yes & Yes \\
\hline Observations & 250 & 200 & 250 & 200 \\
\hline Groups/Clusters & 50 & 50 & 50 & 50 \\
\hline Hansen J statistic (P-value) & 0.79 & 0.87 & 0.67 & 0.91 \\
\hline Wald Test for time dummies & 0 & 0 & 0 & 0 \\
\hline
\end{tabular}

Dependent variable: Share of property

(Clustered) Standard errors robust to heteroskedasticity and serial correlation beneath coefficients Instrumented: User cost

Instruments: User cost (t-1), Ppop2039, Ppop2039 (t-1), Credit, Credit (t-1), In GDPpc (t-1), Shousing $* * * \mathrm{p}<1 \%$

$* * \mathrm{p}<5 \%$

$* \mathrm{p}<10 \%$

number of new cases entering the system, and thus were able to reduce the workload for future periods.

Finally, with respect to the "pending-plus-new cases rate" we can say that, on average, 17.38 cases (summing the pending and the new cases) per 1,000 inhabitants were waiting to be solved. As in other cases, some strong differences by province can be found, from around 1 case per 1,000 inhabitants to 36 .

As occurred with the case of congestion, no significant results are found when the models are computed taking into account the efficacy at the "declaratory" stage.

Table 6 shows the results of the estimations when we consider the pendency cases rate instead of the congestion rate as a measure of efficacy. The results are consistent with the previous ones. An increase of the pendency rate of one point would increase the property share of the province by around $0.16-0.27$ percentage points (around 3,700-6200 houses in Madrid, around 3,300-5,600 in Barcelona and around 1,500-2,500 in Valencia). The results are significant at 5\% level.

Then, an increase in one point of the resolution rate (see Table 7) implies a reduction in the property rate of around $0.82-0.88$ percentage points (that would be approximately 18,800-20,100 houses passing from the property market to the tenancy market and related options in Madrid, 17,000-18,300 in the case of Barcelona, and 1,500-2,500 in the case of Valencia). 
Table 8 Effects of the PPNC rate

\begin{tabular}{|c|c|c|c|c|c|c|}
\hline $\begin{array}{l}\text { Model } \\
\text { Method of estimation } \\
\text { Data transformation }\end{array}$ & $\begin{array}{l}1 \\
\text { 2-Step } \\
\text { GMM FE }\end{array}$ & $\begin{array}{l}2 \\
\text { 2-Step } \\
\text { GMM FE }\end{array}$ & $\begin{array}{l}3 \\
\text { 2-Step } \\
\text { GMM FE }\end{array}$ & $\begin{array}{l}4 \\
\text { 2-Step } \\
\text { GMM FE }\end{array}$ & $\begin{array}{l}5 \\
\text { 2-Step } \\
\text { GMM FE }\end{array}$ & $\begin{array}{l}6 \\
\text { 2-Step } \\
\text { GMM FE }\end{array}$ \\
\hline ppnc*1000 & $\begin{array}{l}0.14 \\
0.07 * *\end{array}$ & & & $\begin{array}{l}0.13 \\
0.07 *\end{array}$ & & \\
\hline ppnc*1000 (t-1) & & $\begin{array}{l}0.18 \\
0.05 * * *\end{array}$ & & & $\begin{array}{l}0.17 \\
0.05 * * *\end{array}$ & \\
\hline ppnc*1000 (t-2) & & & $\begin{array}{l}0.15 \\
0.05 * * *\end{array}$ & & & $\begin{array}{l}0.14 \\
0.05 * * *\end{array}$ \\
\hline User cost & $\begin{array}{l}0.05 \\
0.02 * *\end{array}$ & $\begin{array}{l}0.03 \\
0.02 * *\end{array}$ & $\begin{array}{l}0.05 \\
0.03 *\end{array}$ & $\begin{array}{l}0.04 \\
0.02 * *\end{array}$ & $\begin{array}{l}0.03 \\
0.02\end{array}$ & $\begin{array}{l}0.05 \\
0.02 *\end{array}$ \\
\hline Density & $\begin{array}{l}-0.04 \\
0.02 * *\end{array}$ & $\begin{array}{l}-0.04 \\
0.02 * *\end{array}$ & $\begin{array}{l}-0.04 \\
0.02 * *\end{array}$ & $\begin{array}{l}-0.04 \\
0.02 * *\end{array}$ & $\begin{array}{l}-0.04 \\
0.01 * * *\end{array}$ & $\begin{array}{l}-0.04 \\
0.02 * *\end{array}$ \\
\hline Lawyerspc & & & & $\begin{array}{l}-2.46 \\
1.69\end{array}$ & & \\
\hline Lawyerspc (t-1) & & & & & $\begin{array}{l}-3.10 \\
1.66^{*}\end{array}$ & \\
\hline Lawyerspc (t-2) & & & & & & $\begin{array}{l}-0.41 \\
2.49\end{array}$ \\
\hline Time effects & Yes & Yes & Yes & Yes & Yes & Yes \\
\hline Observations & 200 & 200 & 200 & 200 & 200 & 200 \\
\hline Groups/Clusters & 50 & 50 & 50 & 50 & 50 & 50 \\
\hline $\begin{array}{l}\text { Hansen J statistic } \\
\text { (P-value) }\end{array}$ & 0.99 & 0.98 & 0.99 & 0.99 & 0.99 & 0.99 \\
\hline $\begin{array}{l}\text { Wald Test for time } \\
\text { dummies }\end{array}$ & 0 & 0 & 0.18 & 0.02 & 0.02 & 0.083 \\
\hline
\end{tabular}

Dependent variable: Share of property

(Clustered) Standard errors robust to heteroskedasticity and serial correlation beneath coefficients Instrumented: User cost

Instruments: User cost (t-1), Ppop2039, Ppop2039 (t-1), Credit, Credit (t-1), In GDPpc (t-1), Shousing

$* * * \mathrm{p}<1 \%$

$* * \mathrm{p}<5 \%$

$* \mathrm{p}<10 \%$

Finally, following Table 8, an increase in one point of the "pending-plus-new cases rate" (per 1,000 inhabitants) would increase the property share by around $0.14-0.18$ percentage points (around 3,200-4,100 dwellings in Madrid, 2,900-3,700 in Barcelona and 1,300-1,700 in Valencia).

Open Access This article is distributed under the terms of the Creative Commons Attribution License which permits any use, distribution and reproduction in any medium, provided the original author(s) and source are credited.

\section{References}

Alcaide Inchausti J, Alcaide Guindo P, Alcaide Guindo P (2004) Balance económico regional (autonomías y provincias): años 1995 a 2003. Fundación de las Cajas de Ahorros Confederadas, Madrid

Alcaide Inchausti J, Alcaide Guindo P (2008) Balance económico regional (Autonomías y Provincias) años 2000 a 2007. Fundación de las Cajas de Ahorros Confederadas, Madrid

Arce O, López-Salido D (2007) Housing bubbles. Documento de Trabajo, 0815, Banco de España

Arellano M (2002) Sargan's instrumental variables estimation and the generalized method of moments. J Bus Econ Stat 20:4 
Arruñada B (2003) Property enforcement as organized consent. J Law Econ Org 19(2):401-444

Barceló C (2006) Housing tenure and labour mobility: a comparison across European countries. Documento de Trabajo, 0603, Banco de España

Barrios García JA, Rodríguez Hernández JE (2004) User cost changes, unemployment and homeownership: evidence from Spain. Urban Stud 41(3):563-578

Baum CF, Schaffer ME, Stillman S (2003) Instrumental variables and GMM: estimation and testing. Stata J 3(1):1-31

Bilbao Terol C, García Valiñas MA, Suárez Pandiello J (2006) Intervenciones públicas, haciendas territoriales y precios de la vivienda. Papeles de Economía Española 109:237-256

Blanco R, Restoy F (2007) Have real interest rates really fallen that much in Spain? Documentos de Trabajo $\mathrm{N}^{o} 0704$, Banco de España

Carmignani A, Giacomelli S (2010) Too many lawyers? Litigation in Italian civil courts. Temi di discussione (Working papers), number 745, Banca d'Italia

Casas-Arce P, Saiz A (2010) Owning versus renting: do courts matter. J Law Econ 53(1):137-165

De Leeuw F, Ekanem NF (1971) The supply of rental housing. Am Econ Rev 61(5):806-817

Djankov S, La Porta R, López de Silanes F, Shleifer A (2003) Courts. Q J Econ 118:453-517

Fisher LM, Jaffe AJ (2003) Determinants of international home ownership rates. Hous Finance Int $18(1): 34-42$

García-Vaquero V, Martínez J (2005) Fiscalidad de la vivienda en España. Documentos de Trabajo $\mathrm{N}^{o} 0506$, Banco de España

Green RK (1996) Should the stagnant homeownership rate be a source of concern. Reg Sci Urban Econ 26:337-368

Hardman AM, Ioannides YM (1999) Residential mobility and the housing market in a two-sector neoclassical growth model. Scand J Econ 101:315-335

Hargreaves RV (2003) Determinants of housing tenure choice in New Zealand. Pac Rim Prop Res J 3:203223

Haurin D, Hendershott P, Wachter S (1996) Expected home ownership and real wealth accumulation of youth. NBER working paper 5629

Hendershott PH, Shilling JD (1980) The economics of tenure choice, 1955-79. NBER working paper 543

Henderson JV, Ioannides YM (1983) A model of housing tenure choice. Am Econ Rev 73(1):98-113

Iacoviello M, Minetti R (2003) Financial liberalization and the sensitivity of house prices to Monetary policy: theory and evidence. Manchester School 71(1):20-34

Kumbhakar SC, Lozano-Vivas A (2004) Does deregulation make markets more competitive? Evidence of mark-ups in Spanish savings banks. Appl Financ Econ 14:507-515

Lauridsen J, Skak M (2007) Determinants of homeownership in Denmark. Discussion papers on business and economics no. 2/2007. University of Southern Denmark

Lafayette WC, Haurin DR, Hendershott PH (1995) Endogenous mortgage choice, borrowing constraints and the tenure decision. NBER working paper 5074

Linneman P (1986) A new look at the homeownership decision. Hous Finance Rev 5:159-187

Layard R, Nickell S, Jackman R (1991) Unemployment. Macroeconomic performance and the labor market. Oxford University Press, Oxford

López García M-A (1996) Precios de la vivienda e incentivos fiscales a la vivienda en propiedad en España. Revista de Economía Aplicada 12, IV:37-74

López García MA (2004) Housing, prices and tax policy in Spain. Spanish Econ Rev 6:29-52

Louvot-Runavot C (2001) Le Logement dans l'Union Européenne. INSEE Écon Stat 343:29-50

Mayordomo S (2008) 'Afectan las restricciones financieras al régimen de tenencia de vivienda? Investigaciones Económicas XXXII(3):289-324

Maclennan D, Muellbauer J, Stephens M (1998) Asymmetries in housing and financial market institutions and EMU. Oxford Review of Economic Policy 14(3):54-80

Mora-Sanguinetti JS (2010) A characterization of the judicial system in Spain: analysis with formalism indices. Econ Anal Law Rev 1(2):210-240

Mora-Sanguinetti JS (2011) The regulation of residential tenancy markets in post-war Western Europe: an economic analysis. Eur J Comp Econ 8(1) (forthcoming)

Naredo JM, Carpintero O and Marcos C (2005) Patrimonio inmobiliario y balance nacional de la economía española (1991-2004). FUNCAS 
Padilla J, Llorens V, Pereiras S and Watson N (2007) Eficiencia judicial y eficiencia económica: el mercado crediticio español. En: La Administración Publica que España necesita. Libro Marron. Círculo de Empresarios, Madrid

Rodríguez J, Barrios J (2004) Política fiscal de vivienda en España y forma de tenencia de la vivienda habitual: una valoración empírica a nivel provincial. Reg Sect Econ Stud AEEADE 4(2):85-115

Rosen HS (1979) Housing decisions and the U. S: income tax, an econometric analysis. J Pub Econ 11:1-23

Rosen HS, Rosen TK (1980) Federal taxes and homeownership: evidence from time series. J Polit Econ 88(1):59-75

Sanz JF (2000) Las ayudas fiscales a la adquisición de inmuebles residenciales en la nueva Ley del IRPF: Un análisis comparado a través del concepto de coste de uso. Hacienda Pública Española 155:49-176 Wooldridge JM (2001) Econometric analysis of cross section and panel data. MIT Press, Cambridge 